О.В.Жуленков, аспірант відділу філософських проблем природознавства та екології Інституту філософії імені Г.С.Сковороди НАН України

\title{
ІНТЕГРАЛЬНИЙ ПІДХІД ТА НЕРЕЛІГІЙНА ДУХОВНІСТЬ У ХХІ СТОЛІТТІ
}

Таке поняття, як «нерелігійна духовність», на сьогоднішній день $\epsilon$ досить популярним на Заході та при цьому вельми невизначеним. За допомогою поняття «духовний, але не релігійний» часто ідентифікують себе люди, світоглядна система яких перебуває в опозиції як до світоглядів релігійних традицій, так і до світогляду Просвітництва. Просвітницьке світосприйняття зазвичай розглядається ними, як «недуховне», як «споживацьке». Водночас піддається сумніву духовність релігійних традицій: ії розглядають як «несправжню», оскільки вона є «догматичною», «некритичною» [1]. Серед громадян США близько 30 відсотків дорослого населення позиціонує себе як людей «духовних, але не релігійних» [2]. Особливо охоче ідентифікують свій світогляд за допомогою поняття «нерелігійна духовність» молоді люди віком від 19-ти до 30-ти років [2]. Дуже близьким за значенням до поняття «духовні, але не релігійні» $\epsilon$ поняття «творці культури» (Cultural Creatives), запроваджене П.Реєм та Р.Андерсоном у однойменній монографії [3]. За його допомогою автори позначають людей, цінності яких є відмінними як від цінностей «модерністів» (Moderns), так і від цінностей «традиціоналістів» (Traditionals). Згідно з Реєм та Андерсоном, у США, Західній Європі та Японії частка «творців культури» становить близько $35 \%$ від населення цих країн. Як бачимо, на Заході значна частина людей ідентифікує свій світогляд за допомогою поняття «духовний, але нерелігійний» або за допомогою споріднених понять. Але, як зазначають деякі дослідники, незважаючи на свою популярність, поняття «нерелігійна духовність» лишається на сьогодні вельми метафоричним та невизначеним [4].

Завдання експлікувати поняття «нерелігійна духовність» $\epsilon$ надзвичайно важливим для сучасної філософії науки. Найновіший шквал нано-біо-гено-нейро-інфо-комп'ютерно-мережевих технологій 
значно посилив могутність людства, його здатність змінювати як навколишнє середовище, так і свою власну біо-психо-соціальну природу [5]. Немає жодного сумніву в тому, що цю могутність можуть використовувати як зі світоцентричних, так і з егоцентричних, етноцентричних чи антропоцентричних мотивів. Безсумнівно також, що ницість людських мотивів призводить до експлуатації людини людиною, до експлуатації природи людиною, що, за умови сучасної науково-технологічної могутності людства, означає ризик глобальної екологічної, соціальної та політичної катастрофи. Звідси постають два надзвичайно важливі питання: «Якими мотивами керується вчений, створюючи нові технології: духовними або споживацькими?» та «Яким є ставлення сучасної спільноти вчених до природи: духовним або споживацьким?». Тож дискурс про наукову діяльність нерозривно пов'язаний із дискурсом про духовне сприймання світу. Водночас сучасна наука перебуває у вельми неоднозначних відносинах із традиційними релігійними вченнями. Отже, через усі вищеперелічені причини завдання експлікувати поняття «нерелігійна духовність» $є$ надзвичайно важливим для сучасної філософії науки.

Інтегральний підхід - це сучасна течія філософської думки, представники якої розбудовують «духовний, але не релігійний» світогляд за допомогою еклектичного методу філософування [6]. Він виник з почуття незадоволеності одночасно як світоглядами релігійних традицій, так і секулярними світоглядами Просвітництва. Тому мислителі інтегрального підходу намагаються так взаємодоповнити всі загальновідомі світоглядні системи, щоб отримана метасистема була вільною від недоліків цих систем. Осмислення світоглядів нерелігійної духовності, яке здійснюють прихильники інтегрального підходу, допоможе нам експлікувати метафоричне поняття «духовний, але не релігійний». А сама ця експлікація дасть змогу зрозуміти, які філософські течії виникли теж як спроби розбудувати «духовні, але не релігійні» світогляди, що, своєю чергою, допоможе нам визначити вплив феномену нерелігійної духовності на сучасну науку.

Для того, щоб розрізнити «духовні» та «релігійні» світогляди, Кен Уїлбер, засновник філософії інтегрального підходу, запроваджує поняття «до/над омани». На основі численних емпіричних досліджень у галузі психології він стверджує, що існує три дуги 
розвитку свідомості. Перша з них є дораціональною, доособистісною. Друга - раціональною, особистісною. I третя - надраціональною, надособистісною. Запасти в «до/над оману» означає переплутати дораціональне і надраціональне (оскільки і те, й інше $є$ нераціональним), доособистісне й надособистісне (оскільки і те, й інше є неособистісним). На думку Уїлбера, мислителі доби Просвітництва (друга дуга), які цілком слушно виступили проти догматичної міфічної релігії (перша дуга), «з водою виплеснули й дитину», заперечивши будь-які прояви третьої дуги, що й призвело до катастрофічних наслідків у сучасну добу. Кен Уїлбер стверджує, що «словосполучення «духовний, але не релігійний» здебільшого застосовне до третьої дуги. I навіть якщо люди, котрі описують себе таким чином, не перебувають стабільно в цих вищих, надособистісних хвилях, багато хто з них, схоже, інтуїтивно відчуває ці найвищі реальності. Їм не потрібен егоцентричний магічний культ, або етноцентрична міфічна релігія, просякнута догмою, віровченням і концептуальними віруваннями. Вони шукають безпосереднього досвіду поза словами та концепціями супраментальної, постраціональної, постконвенційної духовності з іiі безпосереднім сприйняттям світосяйної свідомості. Воістину, вони духовні, але не релігійні» [6, 131]. В такому розумінні термін «духовний, але не релігійний» $\epsilon$ дещо тавтологічним, оскільки поняття «духовний», за яким позначають надраціональний та надособистісний світогляд, є протилежним за змістом поняттю «релігійний», яким позначають конвенційні або доконвенційні світогляди (за Піаже), дораціональні та доособистісні світогляди. Але така тавтологічність терміна $є$ виправданою в теперішній час, оскільки багато світових релігій (хоча вони й містять у собі певну кількість постраціональних та надособистісних світоглядних елементів) на $80 \%$ складаються з елементів дораціональних та доособистісних світоглядних, конвенційних або доконвенційних, з міфічних або магічних.

Тепер розглянемо, які течії філософської думки, окрім інтегрального підходу, теж виникли як спроба концептуально втілити «духовний, але не релігійний» світогляд. Почнемо з філософської спадщини Ніцше, з його концепції смерті Бога. Осмислюючи слова Ніцше «Бог помер», Гайдеггер пише: «Звідси зрозуміло, що під цими словами Ніцше розуміє смерть християнського Бога. Однак не менш достовірно, і про це слід знати з самого початку, що у Ніцше, 
в його думці, слова «Бог» і «християнський Бог» служать для позначення надчуттєвого світу взагалі. Бог - найменування сфери ідеї, ідеалів» [7]. Отже, для Ніцше поняття «Бог» означає не лише сукупність догматів християнської церкви, а й будь-які моральні закони, принципи, норми взагалі, будь-які естетичні та гносеологічні канони. Гайдегер, осмислюючи далі творчу спадщину Ніцше, доходить висновку: «Авторитет Бога, авторитет церкви з іiі повчальницькою місією зникає, але на його місце заступає авторитет совісті, сюди ж проривається авторитет розуму. Проти них повстає соціальний інстинкт. Втеча від світу в сферу надчуттєвого замінюється історичним прогресом. Потойбічна мета вічного блаженства перетворюється в земне щастя для більшості. Піклування про релігійний культ змінюється натхненним творенням культури або поширенням цивілізації. Творче начало, яке було колись відмітною рисою біблійного Бога, відзначає тепер людську діяльність. Людська творчість переходить нарешті в бізнес і гешефт» [7]. Як бачимо, за допомогою концепції смерті Бога Ніцше піддає критиці не лише догматику християнської церкви, а ще й раціоналізм модерної доби. Релігійному консерватизмові та модерному раціоналізмові Ніцше протиставляє ірраціоналізм, який визволяє людину від пут будьякої принциповості, від химери совісті, від тиранії Бога як етичного, гносеологічного та естетичного законодавця. Ніцше можна розглядати як першого (або одного з перших) проповідника «духовного, але не релігійного» світогляду в західноєвропейській філософській традиції. Саме з його вчення починається доба подолання картезіансько-кантівського суб' єкта (особистості), доба пошуку шляхів за межі раціоналізму, за межі етичних, естетичних, епістемологічних принципів. Представники таких філософських течій, як філософія життя, герменевтика, філософська антропологія, екзистенціалізм, постмодернізм, тією чи іншою мірою продовжили розбудовувати «духовну, але не релігійну» лінію філософської думки, започатковану Ніцше.

Філософію Ніцше разом з творчістю К'єркегора, Достоєвського та Кафки традиційно вважають предтечею екзистенціалізму. Філософи-екзистенціалісти порушили такі важливі для нашої роботи теми, як сенс і смерть. Вони продемонстрували, що всі сенси, які не витримують зіткнення з глибоким усвідомленням скінченності та негарантованості людського буття, є несправжніми, фальшивими 
сенсами. Вони також, як ніхто інший, відзначали той факт, що існування як окремої людини, так і людства в цілому може бути обірваним у будь-який момент. Смерть неминуче загрожує кожному й усім, світ не дає жодних гарантій. Будь-які сенси, що базуються на певних принципах, ідеалах, цілях, не витримують справді глибокого усвідомлення власної смертності. Людина уникає його, тікає від нього. Таке усвідомлення виражається екзистенційним питанням, яке найкраще за всіх сформулював Л.М.Толстой (творчість його теж вважають однією з предтеч екзистенціалізму): «Питання моє - те, яке в п'ятдесят років призвело мене до самогубства, було найпростішим питанням, яке живе в душі кожної людини, від дурної дитини до наймудрішого старця, - те питання, без якого життя неможливе, як я й відчув це на власному досвіді. Питання полягає в тому: «Що вийде 3 того, що я роблю нині, що буду робити завтра, - що вийде 3 усього мого життя?». Висловлене інакшим чином, питання буде таким: «Навіщо мені жити, навіщо чогось бажати, навіщо що-небудь робити?». Ще інакше висловити питання можна так: «Чи є в моєму житті такий сенс, який би не знищувався неминучою для мене смертю?»» [8].

Якщо людина вбачає сенс свого життя в дотримуванні певних принципів, цілей, ідеалів, то вона є несправжньою, та усвідомлення скінченності й негарантованості людського буття неминуче призведе iii до втрати сенсу, до екзистенційної кризи. Якщо ж людина є справжньою, якщо вона не підпорядковує себе моральному закону, а діє добровільно, то вона здатна мужньо дивитися у вічі неминучої смерті, по-справжньому глибоко усвідомлювати скінченність та негарантованість власного буття. Як писав Сьорен К'єркегор, для такої людини «страх - це запаморочення від свободи». К'єркегор стверджував, що «той, кому довелося істинно навчитися страху, здатен ніби нестися в танці, коли починають награвати страхи скінченного, і учні скінченного втрачають розсудок та мужність» [9]. Схожу ідею висловлював також і Гайдеггер, стверджуючи, що «страх того, хто зважився» («Angst des Verwegenen»), несе в собі «особливий спокій» («eigentumliche Ruhe») [9]. Відтак філософи-екзистенціалісти звернули увагу на фальшивість, несправжність усіх життєвих сенсів, які полягають у додержанні певних етичних, епістемологічних чи естетичних правил, законів, принципів, ідеалів.

Зауважимо, що течія екзистенціалізму виникла як протест 
проти всіх несправжніх сенсів, які втілювали у своїх вченнях філософи доби модерну та доби домодерну. Але, оскільки його ідеї були виражені надзвичайно метафорично та нестрого, то вони не дістали масового поширення. Філософія екзистенціалізму за формою $є$ ближчою до літературних творів, ніж до строгих понятійних систем Канта чи Декарта. Певною мірою можна говорити про те, що екзистенціалісти, як і інтегральні філософи, намагалися концептуально виразити «духовні, але не релігійні» світогляди.

Розпочату Ніцше та екзистенціалістами справу боротьби проти догматизму домодерних релігій та раціоналізму Просвітництва продовжили філософи-постмодерністи. Вони стверджують, що «дві світові війни позначили завершення модерну, закінчення чотирьохвікового існування життєвого світу з усіма його надіями, мріями, цінностями, ідеалами, поняттями, критеріями і способами бачення речей, і саме ці війни ввергли нас водночас у жахливо нову ситуацію, тобто «постмодерністський світ», у якому старі способи мислення, життя і бачення просто не працюють і для яких, значить, повинні бути ще знайдені і випробувані цілком нові шляхи, невідомі модернові» $[10,49]$. Філософія постмодерну є суто критичною течією філософської думки. Постмодерністи намагаються не створювати нових філософських систем, а лише деконструювати існуючі догматичні філософські (метафізичні) системи модерну та домодерну. Щоб здійснити свій грандіозний проект критики усіх світоглядів модерну і до модерну, вони розробили потужний критичний інструментарій, який включає в себе контрфілософію Фуко, ліотарівську критику гранднаративів, деррідіанську деконструкцію. Філософи постмодерну поставили собі за мету розхитати диктатуру Ідеалу, Розуму, Бога, картезіансько-кантівського суб'єкта. Їхня боротьба призвела до емансипації багатьох маргіналізованих дискурсів, до викриття сцієнтизму та редукціонізму, будь-яких проявів тоталітаризму, до розуміння конструктивної природи будь-яких принципів, законів, ідеалів. Як бачимо, філософи-постмодерністи піддали нищівній критиці всю сукупність світоглядів традиційних та секулярних світоглядів модерну та домодерну.

Деякі дослідники порівнюють філософію постмодерну з апофатичною традицією богослов'я, богословського методу, який полягає у вираженні сутності божественного (сакрального) шляхом послідовного заперечення усіх можливих його визначень як несумірних 
йому. Маркус Молц та Роланд Бенедіктер демонструють подібність філософії постмодернізму до негативної теології буддизму таким чином: «Ліотар, Дерріда і навіть Мішель Фуко (1926-84) останніми роками свого життя виявили, що має бути щось, що становить онтологічну основу деконструкції і мовних ігор - щось, що являє собою активну рушійну силу живого процесу думки, яка існує до появи будь-якого розумового змісту. Ці мислителі дійшли усвідомлення своєрідної початкової та нелокалізованої, проте, на певному рівні самоусвідомленої «життєвої енергії» думки, свідомості і присутності: щось вислизає від розуму думаючого, оскільки, розмірковуючий розум завжди ототожнюється зі своїм вмістом і випускає 3 уваги процеси, на яких будується його вміст і з яких він народжується, тобто він випускає 3 уваги процес свого ж власного життя, який $є$ активним проявом творіння через «натхнення». Це натхнення має бути чимось, що передує всім змістам думки, так би мовити, $є$ їх джерелом: чимось, що не було сконструйовано, але що натомість виявляється і діє як передумова всіх конструктів. Це «передпозитивний процес конструювання, який сам по собі є порожнім», «творча порожнеча» (productive void) або «відсутня присутність». Він має являти собою щось на зразок усвідомлення, яке неможливо ідентифікувати, або навіть «чистої свідомості», як би ми це не називали. Уявлення про «творчу порожнечу», запроваджене пізніми постмодерністськими філософами, здається надзвичайно схожим на уявлення про «порожнечу», що розвивалося в буддійській і індуїстській думці і духовній практиці» [11]. Тож можливо говорити про такий спосіб концептуально-понятійного втілення «духовних, але не релігійних» світоглядів, як критична філософія постмодерну.

Справу Ніцше, справу побудови «духовних, але не релігійних» філософських систем, продовжили інтегральні філософи. Якщо екзистенціалізм виник як протест проти секулярних світоглядів модерну та традиційних світоглядів домодерну, якщо філософи постмодернізму піддали ці світогляди деструктивній (деконструктивній) критиці, то інтегральний підхід є конструктивною критикою світоглядів модерну та домодерну. Методологія інтегрального підходу Кена Уїлбера, відповідно до опису Джека Крітендена, складається з трьох послідовних етапів. На першому Уїлбер розкриває всі «часткові істини» різних філософських систем та світоглядів. На другому взаємодоповнює ці філософські та світоглядні системи 
таким способом, щоб отримана внаслідок такого синтезу метасистема включила максимальну кількість вищезазначених «часткових істин». На третьому етапі Уїлбер застосовує здобуту метасистему для критики всіх «вузьких» та «одновимірних» філософських систем [12]. Отже, Уӥлбер крок за кроком вибудовує філософську метасистему (еклектичну систему) з метою найпослідовніше втілити «духовний, але не релігійний» світогляд у філософії.

Щойно з'ясувавши зв'язок між метафоричним поняттям «нерелігійна духовність» та такою течією філософської думки, як інтегральний підхід, ми експлікували поняття «нерелігійна духовність». Довели, що поняття «духовний, але не релігійний» означає такий світогляд, який виходить за межі раціональних принципів та законів картезіансько-кантівського суб'єкта, є трансперсональним (надособистісним) та постраціональним. Далі ми розглянули приклади кількох течій у філософській думці, які є «духовними, але не релігійними»: екзистенціалізм, постмодернізм, інтегральний підхід. Дійшли висновку, що «духовна, але не релігійна» думка в західній філософії має свої витоки у працях Ніцше, який вперше в історії європейської філософії кинув виклик одночасно платонівській традиції філософування та міфічним теологіям домодерну. Цього мислителя можна розглядати як першого (або одного з перших) проповідника «духовних, але не релігійних» світоглядів у західноєвропейській філософській традиції. Саме з його вчення починається доба подолання картезіансько-кантівського суб'єкта (особистості), доба пошуку шляхів за межі раціоналізму, за межі етичних, естетичних, епістемологічних принципів. Представники таких філософських течій, як філософія життя, герменевтика, філософська антропологія, екзистенціалізм, постмодернізм, інтегральний підхід, тією чи іншою мірою продовжили розбудовувати «духовну, але не релігійну» лінію філософської думки, започатковану Ніцше. Цей висновок є надзвичайно важливим для сучасного дискурсу про інтегральний підхід, оскільки серед теоретиків цього підходу сьогодні точаться гострі суперечки щодо ролі інтегрального підходу в історії філософії.

Тепер, оскільки проблема нерелігійної духовності є надзвичайно важливою для сучасної науки, з'ясуємо вплив феномену нерелігійної духовності на еволюцію наукового знання. При цьому передусім треба зважати на той факт, що частка дорослого населення, яке стабільно перебуває на «духовних, але не релігійних» 
стадіях розвитку особистості, становить менше за один відсоток [6, 133]. Але вчені, які перебувають на цій найвищій стадії розвитку свідомості, незважаючи на свою низьку чисельність, мають надзвичайно великий вплив на науковий дискурс. Зокрема, Ервін Шредінгер в своїй відомій праці «Мій погляд на світ» проповідував трансперсональну самоідентифікацію людини та надраціональний сенс життя [13]. Він став одним із засновників квантової механіки, був автором великої кількості оригінальних робіт у багатьох галузях фізики, дослідником феномену життя 3 погляду фізики. Окрім Шредінгера, дуже багато вчених також надихалися у своїх наукових пошуках східним або християнським містицизмом та відкрито заявляли, що дотримуються трансперсональних та надраціональних поглядів на світ. Гарвардський історик Хуан Мігель Марін стверджує, що такі відомі фізики, як Паулі, Вейль, Бом, Едінгтон і навіть Енштейн, цікавилися надраціональними містичними вченнями та 3 містичного погляду інтерпретували терміни і рівняння, які сьогодні лежать в основі квантової механіки [14]. Отже, незважаючи на те, що вплив феномену нерелігійної духовності на еволюцію наукового знання є малодослідженим, можна стверджувати, що дослідники, які піднеслися до «духовного, але не релігійного» світогляду, суттєво впливали та продовжують впливати на науковий дискурс.

Ми проаналізували взаємозв'язок між такою філософською течією, як інтегральний підхід, та поняттям «духовний, але не релігійний», за допомогою якого позначають певний різновид людських світоглядів. У підсумку вдалося, спираючись на теоретичний інструментарій інтегрального підходу, експлікувати метафоричне та невизначене поняття «духовний, але не релігійний». Це дало нам змогу простежити історію становлення «духовних, але не релігійних» світоглядів у європейській філософській думці та зрозуміти роль інтегрального підходу в історії філософії. Такий висновок $\epsilon$ надзвичайно важливим для сучасного дискурсу про інтегральний підхід, оскільки серед теоретиків цього підходу сьогодні точаться гострі суперечки щодо ролі його в історії філософії. Далі, базуючись на здобутому, ми проаналізували вплив феномену нерелігійної духовності на сучасний науковий дискурс. У підсумку з'ясували, що, незважаючи на те, що вплив феномену нерелігійної духовності на еволюцію наукового знання є малодослідженим, можна вважати, що люди, які розвинулися до «духовного, але не релігійного» 
світогляду, здатні суттєво впливати на еволюцію наукового дискурсу. I хоча кількість тих, світогляд яких є справді «духовним, але не релігійним», менша за один відсоток навіть у розвинених країнах, зростання популярності терміна «нерелігійна духовність» засвідчує наявність у значної кількості людей прагнення еволюціонувати до такого світогляду. Якщо така еволюція насправді матиме місце в майбутньому, то вона, наскільки можна судити з наявних даних, супроводжуватиметься значущими трансформаціями теоретичного дискурсу в найрізноманітніших галузях науки.

\section{ЛІТЕРАТУРА}

1. Fuller, Robert $C$. Spiritual but not Religious: Understanding Unchurched America. - New York: Oxford University Press, 2001.

2. Sanders $J$. 'Spiritual but not religious' becoming more common self-identification [Electronic resourse] // Statesman.com - Electronic data. - Mode of access: World Wide Web: http://www.statesman.com/news/news/local/ spiritual-but-not-religious-becoming-more-common-s/nRtHR/ - (viewed on May 6, 2015). - Title from the screen.

3. Ray Paul H.; Sherry Ruth Anderson (2000). The Cultural Creatives: How 50 Million People Are Changing the World. - New York: Harmony Books.

4. Oppenheimer M. Examining the Growth of the «Spiritual but not religious». [Electronic resourse] / Mark Oppenheimer // The New York Times - Electronic data. - Mode of access: World Wide Web: http://www.nytimes.com/ 2014/07/19/us/examining-the-growth-of-the-spiritual-but-not-religious. $\mathrm{html}$ ?\&_r=0 (viewed on May 6, 2015). - Title from the screen.

5. Лук'янеиь В.С., Кравченко О.М., Мороз О.Я. та ін. Індустрія наукових знань доби високої електроніки. Монографія. - К., 2013. - 426 с.

6. Уилбер Кен. Интегральное видение. Краткое введение в революционный интегральный подход к жизни, Богу, вселенной и всему остальному. M., 2009. - 232 c.

7. Хайдегzер М. Слова Ницше «Бог мертв» // Вопросы философии. - 1990. №7. - С. 143-176.

8. Толстой Л.Н. Полное собрание сочинений. - Т. 15. - М., 1913. - С.5-53.

9. Больнов О.Ф. Философия экзистенциализма. - СПб., 1999. - 222 с.

10. Levin D.M. Existentialism at the End of Modernity. Questioning the I's Eyes // Philosophy Today. - 1990. - Vol.34. - № 1. - P.83.

11. Hartwig M., Morgan J. (eds.). Critical realism and spirituality. - Routledge, Taylor \& Francis Group, 2011. - P. 29-74.

12. Уилбер Кен. Око духа: Интегральное видение для слегка свихнувшегося

24 ISSN2078-8142Мультиверсум. Філософський альманах.-2015.-Випуск 1-2(139-140) 
мира / Пер. с англ. В. Самойлова под ред. А. Киселева. - М., 2002. - 476 с. 13. Шредингер Э. Мой взгляд на мир. Изд. 2-е. $\square-\square$ М., 2009. - 146 с.

14. Marin J.M. Mysticism in Quantum Mechanics: the forgotten controversy. Harvard, Eur. J. Phys. - 30 (2009). - P.807-822.

Жуленков О.В. Інтегральний підхід та нерелігійна духовність у ХХІ столітті.

Сьогодні у західних країнах стрімко зростає популярність поняття «нерелігійна духовність». За його допомогою ідентифікують свій світогляд люди, для яких є однаково неприйнятними як релігійні світогляди домодерну, так і раціональні світогляди модерну. Та, незважаючи на свою популярність, це поняття є метафоричним та невизначеним. У статті на основі теоретичних напрацювань мислителів такої течії філософської думки, як інтегральний підхід, експліковано поняття «нерелігійна духовність». Проведено історичний аналіз європейської філософії з метою виділити «духовну, але не релігійну» лінію розвитку філософської думки. На окремих прикладах розглянуто вплив учених з «духовним, але не релігійним» світоглядом на еволюцію наукового знання.

Ключові слова: нерелігійна духовність, інтегральний підхід, третя дуга, еволюція свідомості, постраціональність, світогляд.

Жуленков А.В. Интегральный подход и нерелигиозная духовность в ХХІ столетии.

Сегодня в западных странах стремительно возрастает популярность понятия «нерелигиозная духовность». С его помощью идентифицируют свое мировоззрение люди, для которых одинаково не приемлемы как религиозные мировоззрения домодерна, так и рациональные мировоззрения модерна. Несмотря на свою популярность, это понятие является метафорическим и неопределенным. В статье на основе теоретических наработок мыслителей такого течения философской мысли, как интегральный подход, эксплицировано понятие «нерелигиозная духовность». Проведен исторический анализ европейской философии с целью выделить «духовную, но не религиозную» линию в развитии философской мысли. На отдельных примерах рассмотрено влияние ученых с «духовным, но не религиозным» мировоззрением на эволюцию научного знания.

Ключевые слова: нерелигиозная духовность, интегральный подход, третья дуга, эволюция сознания, пострациональность, мировоззрение.

Zhulenkov A. Integral theory and non-religious spirituality in the $21^{\text {st }}$ century.

Today the popularity of the concept of «spiritual but not religious» is rapidly increasing in Western countries. This concept usually use for self- 
identification people, which worldview is in opposition to the pre-modern religious world-views and to the rational worldviews of modernity at the same time. Despite its popularity, this concept is vague and metaphorical. The concept of «non-religious spirituality» is explicated on the basis of theoretical heritage of integral philo-sophy. The article gives a historical analysis of European philosophy with the aim to identify the «spiritual but not religious» philosophical direction. The influence of scientists with «spiritual but not religious» worldview on the evolution of scientific knowledge is analyzed on particular examples.

Key words: non-religious spirituality, integral theory, the third order, the evolution of consciousness, post-rational, worldview. 